\title{
Control of contaminants in the in vitro establishment of Guadua latifolia ${ }^{1}$
}

\author{
João Ricardo Avelino Leão ${ }^{2}$, Andréa Raposo ${ }^{3}$, \\ Ana Claudia Lopes da Silva ${ }^{4}$, Paulo de Tarso Barbosa Sampaio ${ }^{4}$
}

\section{ABSTRACT}

The Amazonian bamboo forests are located in an important region of high biodiversity in Brazil, Peru and Bolivia, forming the largest native bamboo forest reserve in the world. However, the bamboos from these forests have characteristics that hinder their propagation. This study aimed to evaluate the biocide action of a plant preservative mixture for controling contaminants, during the in vitro establishment of Guadua latifolia (Bonpl.) Kunth, a species native to the region. Nodal segments were cultured in a semi-solid medium containing Plant Preservative Mixture $\left(\mathrm{PPM}^{\mathrm{TM}}\right)$, at the concentrations of $0 ; 1 ; 2$; and $3 \mathrm{~mL} \mathrm{~L}^{-1}$, and supplemented with $2 \mathrm{mg} \mathrm{L}^{-1}$ of 6-benzylaminopurine. The analyzed variables were number of shoots, percentage of bacterial and fungal contamination, and shoot survival. The treatments with the synthetic biocide were efficient in controlling the in vitro contamination caused by bacteria and fungi (Fusarium sp.), also presenting the highest survival rate of regenerated shoots. For the in vitro establishment of this native bamboo species, the use of $2 \mathrm{~mL} \mathrm{~L}^{-1}$ of $\mathrm{PPM}^{\mathrm{TM}}$ is recommended.

KEYWORDS: Bamboo, micropropagation, microbial contamination.

\section{INTRODUCTION}

Bamboos have been subjected to different biotechnological interventions, in order to understand their growth and behavior, or for the commercial use of this valuable non-timber resource. This fastgrowing renewable resource has multiple uses, including construction material, coal production, paper, cellulose, and pharmaceutical and food industry applications, with an increasing demand

\section{RESUMO}

Controle de contaminantes no estabelecimento in vitro de Guadua latifolia

As florestas amazônicas de bambu estão localizadas em uma importante região de alta biodiversidade no Brasil, Peru e Bolívia, formando a maior reserva florestal de bambu nativo do mundo. Contudo, os bambus dessas florestas possuem características que dificultam sua propagação. Objetivou-se avaliar a ação biocida de mistura preservativa para plantas no controle de contaminantes, durante o estabelecimento in vitro de Guadua latifolia (Bonpl.) Kunth, uma espécie nativa da região. Segmentos nodais foram cultivados em meio de cultura semissólido contendo mistura preservativa para plantas $\left(\mathrm{PPM}^{\mathrm{TM}}\right)$, nas concentrações de $0 ; 1 ; 2$; e $3 \mathrm{~mL} \mathrm{~L}^{-1}$, e suplementado com $2 \mathrm{mg} \mathrm{L}^{-1}$ de 6-benzilaminopurina. As variáveis analizadas foram número de brotos, porcentagem de contaminação bacteriana e fúngica, e sobrevivência de brotos. Os tratamentos com o biocida sintético foram eficientes no controle da contaminação in vitro ocasionada por bactérias e fungos (Fusarium sp.), apresentando, também, a maior taxa de sobrevivência dos brotos regenerados. Para o estabelecimento in vitro dessa espécie nativa de bambu, recomenda-se o uso de $2 \mathrm{~mL} \mathrm{~L}^{-1}$ de $\mathrm{PPM}^{\mathrm{TM}}$.

PALAVRAS-CHAVE: Bambu, micropropagação, contaminação microbiana.

for and awareness of its vast potential (Goyal \& Sen 2016, Thapa et al. 2018).

The Guadua genus consists of tropical bamboos with unique characteristics, such as renewability, durability, versatility and sustainability. Natural bamboos from the Brazilian Acre state have been used in rural and urban construction, thereby reducing the pressure on forests (Miranda et al. 2017).

Amazonia has the largest natural forest with bamboo in the world, covering $161,500 \mathrm{~km}^{2}$ of

${ }^{1}$ Received: May 20, 2020. Accepted: July 08, 2020. Published: Aug. 21, 2020. DOI: 10.1590/1983-40632020v5063541.

${ }^{2}$ Instituto Federal de Educação, Ciência e Tecnologia do Acre, Rio Branco, AC, Brasil. E-mail/ORCID: joao.aleao@ifac.edu.br/0000-0002-0669-4715.

${ }^{3}$ Empresa Brasileira de Pesquisa Agropecuária (Embrapa Gado de Corte), Campo Grande, MS, Brasil.

E-mail/ORCID: andrea.raposo@embrapa.br/0000-0001-9640-4218.

${ }^{4}$ Instituto Nacional de Pesquisas da Amazônia, Manaus, AM, Brasil.

E-mail/ORCID: acl.engenhariaflorestal@hotmail.com/0000-0002-7954-8989, sampaio@inpa.gov.br/0000-0003-0254-7651. 
Brazil, Peru and Bolivia. The species life cycle is estimated at 27-28 years (Carvalho et al. 2013), and this area is home to the species G. weberbaueri, G. sarcocarpa, G. superba and G. paniculata, with the first two exhibiting a general and the latter two a specific distribution (Daly \& Silveira 2008). The G. latifolia culm was reported by Miranda (2020) as having pontential for industrial applications.

Tradicional bamboo breeding is difficult, because of its peculiar flowering patterns and scarce production of seed sets. Thus, in vitro regeneration is the best alternative method for the large-scale production of bamboo seedlings. Current available information on in vitro regeneration methods and their different factors is useful for increasing the seedlings survival rate of different bamboo species (Verma \& Mishra 2018).

As such, several species have been sucessfully micropropagated, including Bambusa edulis (Lin et al. 2005), Bambusa balcooa (Mudoi \& Borthakur 2009), Dracaena sanderiana (Gradaille et al. 2010), Bambusa nutans (Mehta et al. 2011), Bambusa arundinacea (Kalaiarasi et al. 2014), Dendrocalamus asper and Bambusa oldhamii (Araujo et al. 2015), Dendrocalamus strictus (Goyal et al. 2015), Bambusa vulgaris (Ribeiro et al. 2016) and Drepanostachyum falcatum (Saini et al. 2016).

Few studies with efficent establishment protocols for native Amazonian Guadua bamboos have been conducted for the in vitro propagation of Guadua angustifolia (Jiménez et al. 2006, Gutiérrez et al. 2016). According to Nadha et al. (2012), the common problem of bacterial growth around in vitro sprouts in G. angustifolia tissue culture is due to Pantoea agglomerans and Pantoea ananatis, while Pasqualini et al. (2019) identified endophytic fungi, such as Fusarium sp., in in vitro bamboo cultures, increasing the current knowledge regarding the diversity of fungi associated with bamboo.

Thus, the present study aimed to evaluate the biocide action of Plant Preservative Mixture $\left(\mathrm{PPM}^{\mathrm{TM}}\right)$ for controling contaminants in the in vitro establishment of Guadua latifolia (Bonpl.) Kunth.

\section{MATERIAL AND METHODS}

The study was conducted at the Embrapa Acre, in Rio Branco, Acre state, Brazil, from January to March 2017. Guadua latifolia bamboo seedlings were collected at the Reserva Extrativista Chico Mendes, in Assis Brasil, Acre state (10 43'02.2"S and $69^{\circ} 24^{\prime} 06.5^{\prime \prime} \mathrm{W}$ ), and planted in a greenhouse, in a mixture of soil, commercial substrate and organic material (1:1:1). Herborized material was deposited at the herbarium of the Universidade Federal do Acre, in Rio Branco.

The $\mathrm{pH}$ of the culture medium was ajusted to 5.8, with sodium hydroxide $(\mathrm{NaOH})$ and chloridric acid $(\mathrm{HCl})$, and autoclaved for 15 minutes. After inoculation, the culture was stored in a room at the temperature of $25 \pm 2{ }^{\circ} \mathrm{C}$ and 16-hour photoperiod, under white light and photosynthetic photon flux density of $30 \mu \mathrm{mol} \mathrm{m}{ }^{-2} \mathrm{~s}^{-1}$.

The nodal segments collected from the greenhouse seedling (Figure 1A) in January were taken to the laboratory and reduced to $2.5 \mathrm{~cm}$ explants with one axillary bud (Figure 1B). The thorn and sheath were removed to expose the bud. Next, they
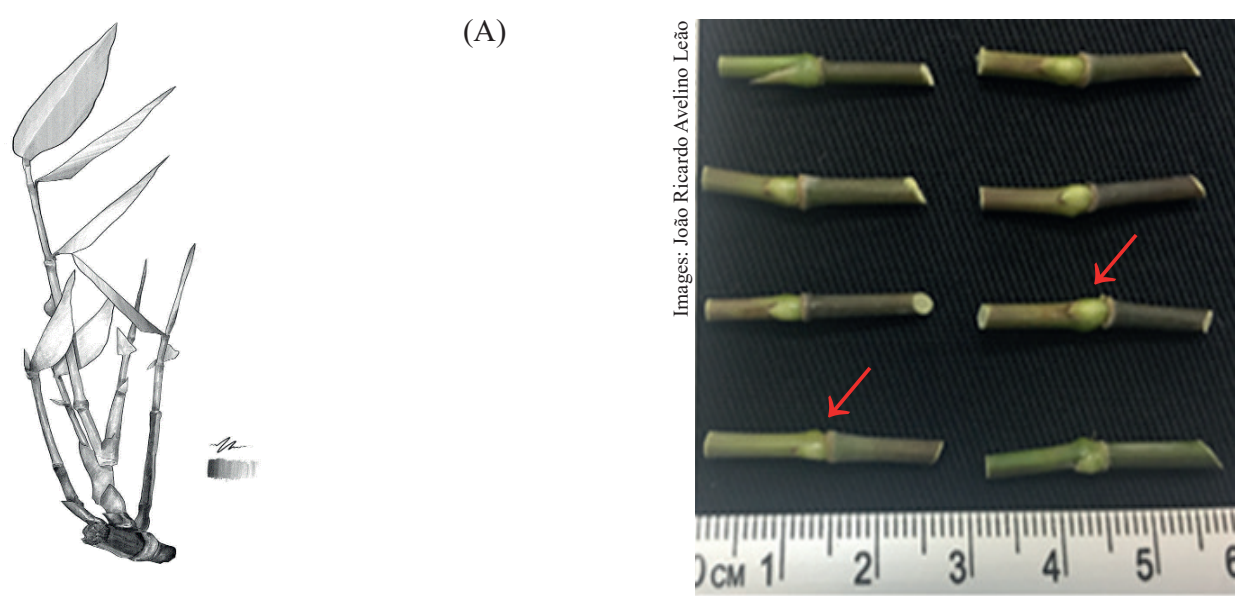

Figure 1. Guadua latifolia seedling (A) and explants selected from the greenhouse for establishment with one axillary bud (arrows) (B). 
were washed with commercial soap, brushed for 5 minutes and then rewashed with distilled and autoclaved water.

The explants were taken to an aseptic room and immersed in a solution containing Amistar ${ }^{\mathrm{TM}}$ fungicide $\left(0.34 \mathrm{~g} \mathrm{~L}^{-1}\right)$ and the antibacterial agent benzalkonium chloride $\left(0.5 \mathrm{~g} \mathrm{~L}^{-1}\right)$, for 10 minutes. The solution was then discarded, and the explants washed in distilled and autoclaved water. Next, they were submerged in $70 \%$ alcohol $(\mathrm{v} / \mathrm{v})$, for one minute. The explants were kept in contact with $2.5 \%$ sodium hyplochlorite and three drops of Tween ${ }^{\mathrm{TM}}$ for 10 minutes, and then washed in distilled and autoclaved water.

In a vertical laminar air flow cabinet, the explants were inoculated in a $250-\mathrm{mL}$ glass flask containing $30 \mathrm{~mL}$ of semi-solid Murashige \& Skoog (1962) culture medium and sacarose $\left(30 \mathrm{~g} \mathrm{~L}^{-1}\right)$ solidified with agar $\left(6 \mathrm{~g} \mathrm{~L}^{-1}\right)$, as well as $2 \mathrm{mg} \mathrm{L}^{-1}$ of 6-benzylaminopurine and $0 ; 1 ; 2$; and $3 \mathrm{~mL} \mathrm{~L}^{-1}$ of $\mathrm{PPM}^{\mathrm{TM}}$.
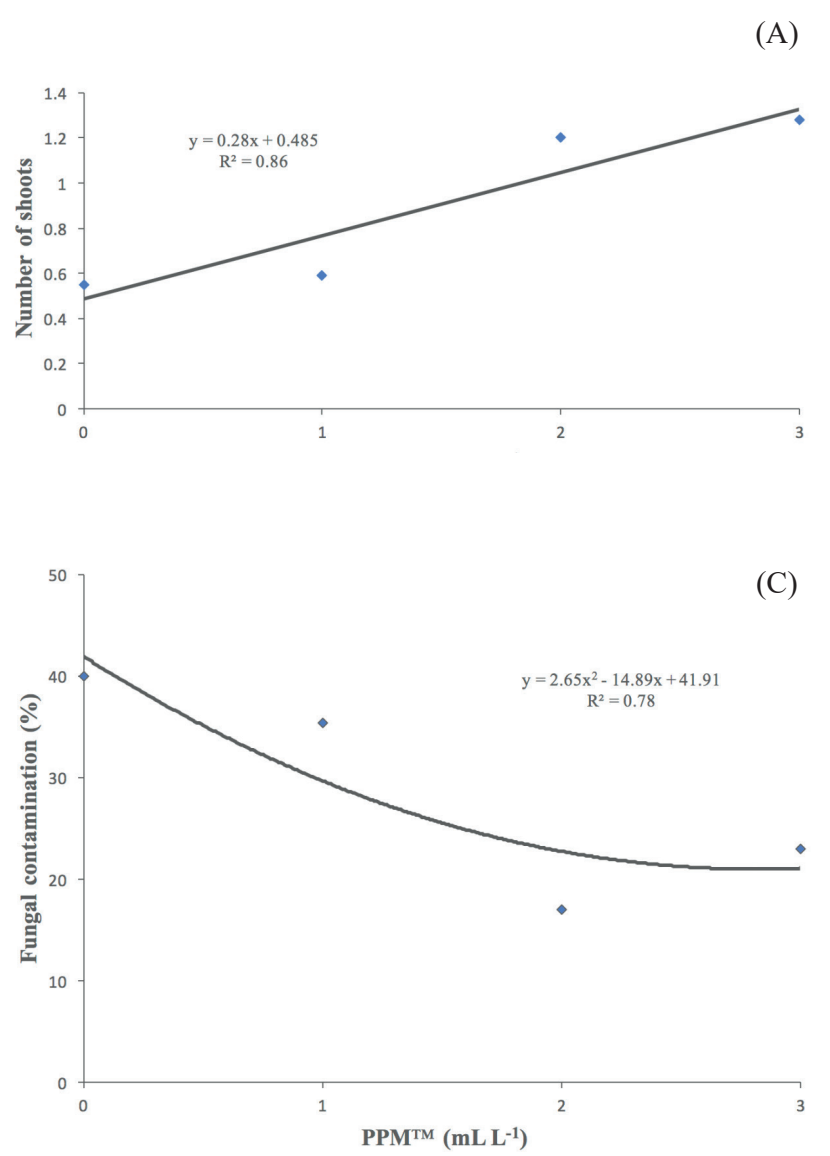

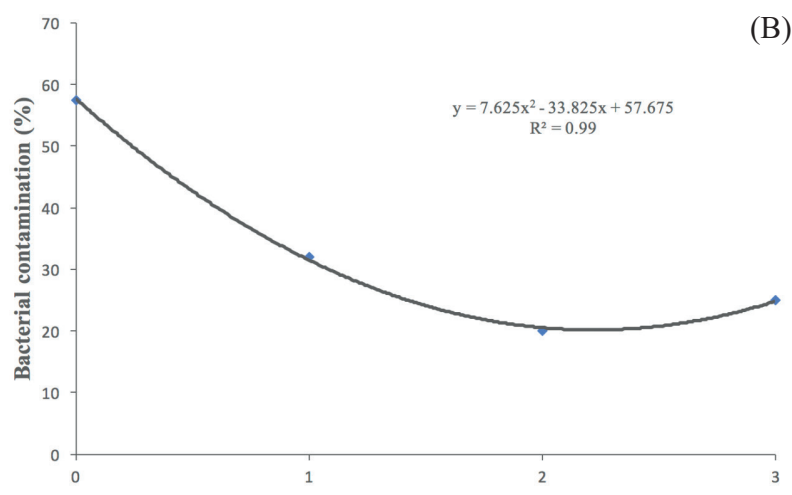

A completely randomized design was used, with four treatments, twenty-four replications and four explants per flask. The analyzed variables, after 15 days of incubation, were number of shoots, bacterial and fungal contamination, and shoot survival. The effect of the treatments was evaluated by analysis of variance (Anova) and means by linear and quadratic regression, using the Assistat 7.7 software (Silva \& Azevedo 2016).

\section{RESULTS AND DISCUSSION}

The treatments with Plant Preservative Mixture $\left(\mathrm{PPM}^{\mathrm{TM}}\right)$ were significant for all the variables of interest, and linear-quadratic regression models were fit to all the affected variables (Figures 2A-D). Bud regeneration was observed at four days after the establishment, and the axillary bud induction in the semi-solid culture medium was completely developed after 15 days of incubation. The highest

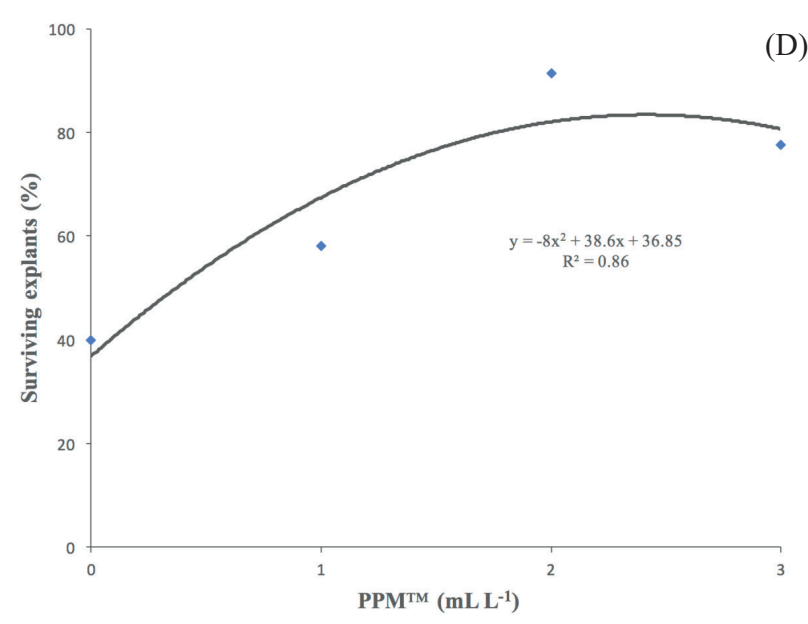

Figure 2. Effect of Plant Preservative Mixture (PPM $\left.{ }^{\mathrm{TM}}\right)$ on number of shoots (A), bacterial (B) and fungal (C) contamination, and shoot survival (D), in nodal segments of Guadua latifolia, after 15 days of in vitro culture in Murashige \& Skoog (1962) semi-solid medium. 
number of shoots was observed for the concentration of $3 \mathrm{~mL} \mathrm{~L}^{-1}$ of PPM ${ }^{\mathrm{TM}}$ in the culture medium (Figure 2A). Pasqualini et al. (2019) reported similar results for Bambusa oldhamii, using the same concentration of the biocide.

For the Guadua genus, PPM ${ }^{\mathrm{TM}}$ was used as a disinfection method on the micropropagation of G. angustifolia (Jiménez et al. 2006), representing a low use, when compared with other more aggressive bamboo surface sterilizing agents, such as mercuric chloride (Ray \& Ali 2016, Sandhu et al. 2018), antibiotics, fungicides and other chemical substances, including bavistin, streptomycin, tetracycline, benomyl, agrimycin and cercobin (Jiménez et al. 2006, Khan et al. 2014).

In addition, PPM ${ }^{\mathrm{TM}}$ is widely recommended to disinfect explants, as observed in vitro for Cucumis melo, Petunia hybrida, Nicotiana tabacum (Compton \& Koch 2001, Miyazaki et al. 2010), blueberry (Huh et al. 2015) and papaya (Thomas et al. 2017). However, the role of bacteria in micropropagated plants has recently been questioned, because certain bacteria could have a positive effect on explants, increasing the multiplication and rooting in plant tissue culture (Orlikowska et al. 2017).

According to Niedz (1998), $\mathrm{PPM}^{\mathrm{TM}}$ is a mixture of methylchloroisothiazolinone and methylisothiazolinone that belongs to the isothiazolone group, which is used to prevent and reduce the growth of organic contaminants in the culture medium of micropropagated plants, acting as electrophiles in the reaction of cysteine and glutathione.

The performance of the synthetic biocide favored an increase in the number of shoots, because it was decisive in the shoot survival, as well as in eliminating and controlling contaminating agents in the culture medium, making it possible to successfully establish the plant material in the laboratory. The lowest rate of bacterial and fungal contamination (Figures 2B and 2C) was observed for a PPM ${ }^{\mathrm{TM}}$ concentration of $2 \mathrm{~mL} \mathrm{~L}^{-1}$ (Figure $3 \mathrm{~A}$ ), the same dose indicated by the manufacturer for woody plants (PCT 2019), followed by $3 \mathrm{~mL} \mathrm{~L}^{-1}$ of PPMTM (Figure 3B).

In the present study, there was a reduction of bacterial and fungal contamination in the treatments where the biocide was present. The control treatment showed a higher percentage of microbial contamination due to the absence of $\mathrm{PPM}^{\mathrm{TM}}$ in the culture medium (Figures 2B and 2C).

The contamination of plant material during the in vitro culture is largely due to the presence of endophytic microorganisms resistant to the disinfestation process (Nadha et al. 2012). In addition, this process removes bacteria from surfaces, but those inhabiting inner tissues and organs are usually unaffected by these sterilants. In vitro conditions are designed for optimal plant growth and development, but are also often ideal for bacterial multiplication (Orlikowska et al. 2017).

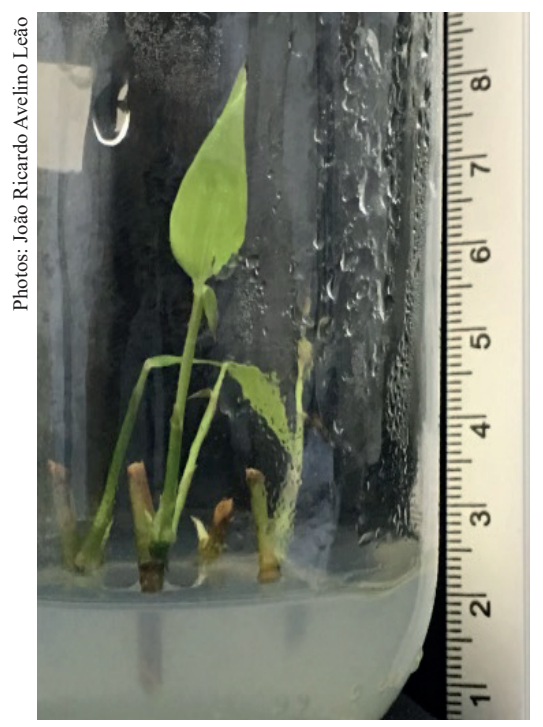

(A)

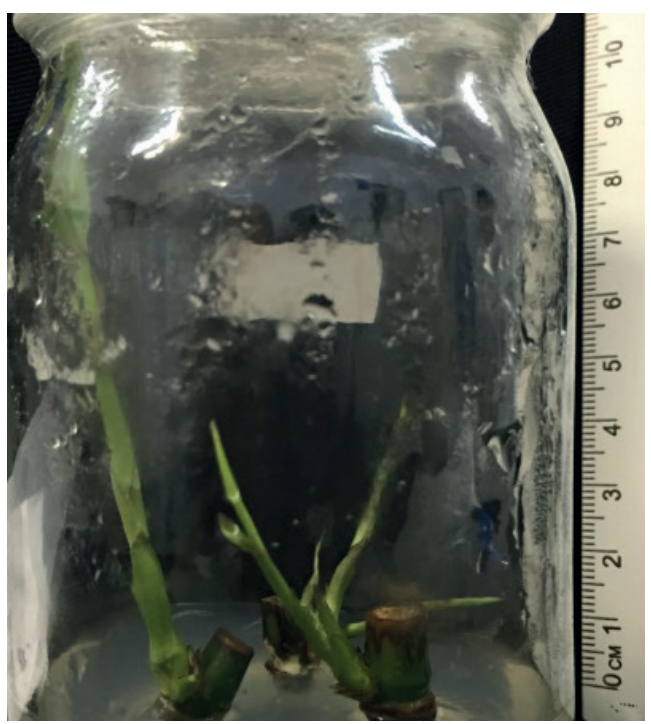

Figure 3. Establishment of Guadua latifolia with no contamination. Axillary bud of bamboo in Murashige \& Skoog (1962) semi-solid medium, in $2 \mathrm{~mL} \mathrm{~L}^{-1}(\mathrm{~A})$ and $3 \mathrm{~mL} \mathrm{~L}^{-1}$ of Plant Preservative Mixture (PPM ${ }^{\mathrm{TM}}$ ), after 15 days of incubation (B). 
For the in vitro propagation of Guadua, the emergence of endogenous contamination is a major problem in the establishment process, since the successful micropropagation depends on the elimination of these microorganisms through an efficient disinfestation protocol (Nadha et al. 2012).

Positive effects of PPM ${ }^{\mathrm{TM}}$ in bamboo tissue culture were reported by Jiménez et al. (2006), who studied the in vitro establishment of Guadua angustifolia and observed that the concentration of $2 \mathrm{~mL} \mathrm{~L}^{-1}$ is efficient in controlling contamination, as well as reducing fungal and bacterial contamination to $11 \%$, when the explant source originated in the greenhouse. Their results were similar to those reported here, and the fungal contaminant was identified as Fusarium sp. (Figure 4).

The PPM ${ }^{\mathrm{TM}}$ disinfectant agent contains active ingredients that penetrate the cell wall of fungi and bacteria, inhibiting the activity of key enzymes from the metabolism of central cycles such as citric acid and the electron transport chain, thereby neutralizing and preventing the growth of contaminants such as endogenous bacteria (Compton \& Koch 2001).

The highest survival rates of the in vitro shoots were around $93 \%$ and $78 \%$ for the $2 \mathrm{~mL} \mathrm{~L}^{-1}$ and $3 \mathrm{~mL} \mathrm{~L}^{-1}$ of PPM ${ }^{\mathrm{TM}}$ tested concentrations, respectively. The evaluated treatments were statistically different from the control, which exhibited a survival rate of $40 \%$ (Figure 2 D).

The PPM ${ }^{\mathrm{TM}}$ concentration may be detrimental to the development of in vitro explants. In this experiment, it was observed that the use of 6-benzylaminopurine (BA) in establishment trials

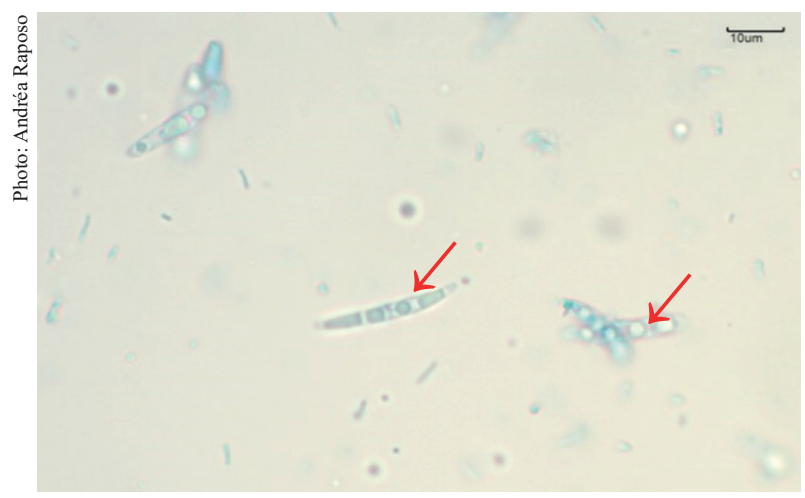

Figure 4. Morphological aspect of Fusarium sp. $($ bar $=10 \mu \mathrm{m})$ found in the nodal segments of bamboo (Guadua latifolia) inoculated in culture medium. Note the light-colored half moon-shaped fusiform conidium and transverse septa (arrows). favors the emergence of in vitro shoots. Jiménez et al. (2006) corroborate the hypothesis that bud responses to the exogenous BA dosage are positive for the Guadua species, inducing multiple shoots. The authors also recommend the Murashige \& Skoog (1962) semi-solid culture medium as a promoter of a suitable environment for bamboo tissue culture.

In terms of bud breaking and shoot proliferation, BA showed to be more effective than other cytokinins for several bamboo species, including Dendrocalamus strictus (Goyal et al. 2015), but the synergistic effect of BA and Kin were better for shoot induction and multiplication in Bambusa arundinacea (Kalaiarasi et al. 2014).

\section{CONCLUSION}

The establishment of bamboo using $2.0 \mathrm{mLL}^{-1}$ of Plant Preservative Mixture $\left(\mathrm{PPM}^{\mathrm{TM}}\right)$ is more efficient against bacterial and fungal attack, and beneficial for shoot regeneration and survival. The fungal contaminant was identified as Fusarium sp.

\section{REFERENCES}

ARAUJO, C. H. P.; CARNEIRO, L. L.; ARAUJO, C. L. P.; SIBOV, S. T. Estabelecimento in vitro de duas espécies de bambu: Dendrocalamus asper (Schultes f.) Backer ex Heyne e Bambusa oldhamii Munro. Enciclopédia Biosfera, v. 11, n. 22, p. 1172-1182, 2015.

CARVALHO, A. L. de; NELSON, B. W.; BIANCHINI, M. C.; PLAGNOL, D.; KUPLICH, T. M.; DALY, D. C. Bamboo-dominated forests of the southwest Amazon: detection, spatial extent, life cycle length and flowering waves. Plos One, v. 8, n. 1, p. 1-13, 2013.

COMPTON, M. E.; KOCK, J. M. Influence of Plant Preservative Mixture $\left(\mathrm{PPM}^{\circledR}\right)$ on adventitious organogenesis in melon, petunia and tobacco. In Vitro Cellular \& Developmental Biology-Plant, v. 37, n. 2, p. 259-261, 2001.

DALY, D. C.; SILVEIRA, M. First catalogue of the flora of Acre, Brasil. Rio Branco: Edufac, 2008.

GOYAL, A. K.; PRADHAN, S.; BASISTHA, B. C.; SEN, A. Micropropagation and assessment of genetic fidelity of Dendrocalamus strictus (Roxb.) Nees using RAPD and ISSR markers. 3Biotech, v. 5, n. 4, p. 473-482, 2015.

GOYAL, A. K.; SEN, A. In vitro regeneration of bamboos, the "green gold": an overview. Indian Journal of Biotechnology, v. 15, n. 1, p. 9-16, 2016. 
GRADAILLE, M. D.; RODRÍGUEZ, D. P.; MÁS, Y. L.; TORRIJO, F. S. Propagación in vitro de bambú chino (Dracaena sanderiana L.). Ciencia y Tecnología, v. 3, n. 1, p. 7-13, 2010.

GUTIÉRREZ, L. G.; FRANCO, R. L.; PINZÓN, T. M. Micropropagation of Guadua angustifolia Kunth (Poaceae) using a temporary immersion system RITA. African Journal of Biotechnology, v. 15, n. 28, p. 15031510, 2016.

HUH, Y. S.; LEE, J. K.; KIM, I. J.; KANG, B. G.; LEE, K. Y. Effect of biocide addition on plantlet growth and contamination occurrence during the in vitro culture of blueberry. Journal of Plant Biotechnology, v. 42, n. 2, p. 111-116, 2015.

JIMÉNEZ, V. M.; CASTILLO, J.; TAVARES, E.; GUEVARA, E.; MONTIEL, M. In vitro propagation of the neotropical giant bamboo, Guadua angustifolia Kunth, through axillary shoot proliferation. Plant Cell, Tissue and Organ Culture, v. 86, n. 3, p. 389-395, 2006.

KALAIARASI, K.; PALANIVEL, S.; SUBRAMANIAM, S. Development of an efficient protocol for plant regeneration from nodal explants of recalcitrant bamboo (Bambusa arundinacea Retz. Willd) and assessment of genetic fidelity by DNA markers. Agroforest Systems, v. 88, n. 3 , p. 527-537, 2014.

KHAN, H. R.; BURLA, S.; SIRI, N.; LAVANYA, P. Effect of nutrient media and phytohormones on in vitro establishment of Bambusa balcooa Roxb. International Letters of Natural Sciences, v. 12, n. 1, p. 1-11, 2014.

LIN, C. S.; LIN, C. C.; CHANG, W. C. Shoot regeneration, re-flowering and post flowering survival in bamboo inflorescence culture. Plant Cell, Tissue and Organ Culture, v. 82, n. 3, p. 243-249, 2005.

MEHTA, R.; SOOD, A.; SHARMA, R. K. Induction of somatic embryogenesis and analysis of genetic fidelity of in vitro-derived plantlets of Bambusa nutans Wall. using AFLP markers. European Journal of Forest Research, v. 130, n. 5, p. 729-736, 2011.

MIRANDA, A. F. A.; FILGUEIRAS, T. S.; RIBEIRO, D. G. Anatomic study of culm internodes of Guadua latifolia (Poaceae: Bambusoideae) occurring in Acre Brazil. Brazilian Journal of Botany, v. 43, n. 4, p. 663$641,2020$.

MIRANDA, E. M. de; AFONSO, D. G.; PONTES, S. M. de A.; SOUZA, J. C. N. de; LIMA, D. do N.; FREITAS JÚNIOR, J. L. Estrutura populacional e o potencial de uso de Guadua cf. superba na região do Alto Acre. In: DRUMOND, P. M.; WIEDMAN, G. (org.). Bambus do Brasil: da biologia à tecnologia. Rio de Janeiro: $\mathrm{ICH}$, 2017. p. 161-178.
MIYAZAKI, J.; TAN, B. H.; ERRINGTON, S. G. Eradication of endophytic bacteria via treatment for axillary buds of Petunia hybrida using Plant Preservative Mixture (PPM ${ }^{\circledR}$. Plant Cell, Tissue and Organ Culture, v. 102, n. 3, p. 365-372, 2010.

MUDOI, K. D.; BORTHAKUR, M. In vitro micropropagation of Bambusa balcooa Roxb. through nodal explants from field-grown culms and scope for upscaling. Current Science, v. 96, n. 7, p. 962-966, 2009.

MURASHIGE, T.; SKOOG, F. A revised medium for rapid growth and bioassays with tobacco tissue cultures. Physiologia Plantarum, v. 15, n. 3, p. 473-497, 1962.

NADHA, H. K.; SALWAN, R.; KASANA, R. C. Identification and elimination of bacterial contamination during in vitro propagation of Guadua angustifolia Kunth. Pharmacognosy Magazine, v. 8, n. 30, p. 93-97, 2012.

NIEDZ, R. P. Using isothiazolone biocides to control microbial and fungal contaminants in plant tissue cultures. Horttechnology, v. 8, n. 4, p. 598-601, 1998.

ORLIKOWSKA, T.; NOWAK, K.; REED, B. Bacteria in the plant tissue culture environment. Plant Cell Tissue and Organ Culture, v. 128, n. 3, p. 487-508, 2017.

PASQUALINI, A. P. de A.; SANTOS, M. C. dos; SANT'ANNA-SANTOS, B. F.; FRAGA, H. P. de F.; QUOIRIN, M. Cultura in vitro e diversidade de fungos endofíticos em Bambusa oldhamii. Pesquisa Agropecuária Tropical, v. 49, e53760, 2019.

PLANT CELL TECHNOLOGIES (PCT). PPM: Plant Preservative Mixture product information. 2019. Available at: https://www.plantcelltechnology.com/about-ppm/. Access on: Jan. 11, 2019.

RAY, S. S.; ALI, N. Biotic contamination and possible ways of sterilization: a review with reference to bamboo micropropagation. Brazilian Archives of Biology and Technology, v. 59, n. 1, p. 1-12, 2016.

RIBEIRO, A. dos S.; BRONDANI, G. E.; TORMEN, G. C. R.; FIGUEIREDO, A. J. R. de. Cultivo in vitro de bambu em diferentes sistemas de propagação. Nativa, v. 4, n. 1, p. 15-18, 2016.

SAINI, H.; ARYA, I. D.; ARYA, S.; SHARMA, R. In vitro micropropagation of Himalayan weeping bamboo, Drepanostachyum falcatum. American Journal of Plant Sciences, v. 7, n. 9, p. 1317-1324, 2016.

SANDHU, M.; WANI, S. H.; JIMÉNEZ, V. M. In vitro propagation of bamboo species through axillary shoot proliferation: a review. Plant Cell Tissue and Organ Culture, v. 132, n. 1, p. 27-57, 2018.

SILVA, F. A. S.; AZEVEDO, C. A. V. The Assistat software version 7.7 and its use in the analysis of experimental data. 
African Journal of Agricultural Research, v. 11, n. 39, p. 3733-3740, 2016.

THAPA, P.; BHATTACHARYA, A.; SOOD, P.; DEVI, K.; SOOD, A. Advances in bamboo biotechnology: present status and future perspective. Biotechnologies of Crop Improvement, v. 1, n. 1, p. 243-265, 2018.

THOMAS, P.; AGRAWAL, M.; BHARATHKUMAR, C. B. Use of Plant Preservative Mixture ${ }^{\mathrm{TM}}$ for establishing in vitro cultures from field plants: experience with papaya reveals several $\mathrm{PPM}^{\mathrm{TM}}$ tolerant endophytic bacteria. Plant Cell Reports, v. 36, n. 1, p. 1717-1730, 2017.

VERMA, P.; MISHRA, N. A review in vitro regeneration of bamboo plants by plant culture techniques. International Journal of Advances in Science, Engineering and Technology, v. 6, n. 1, p. 58-67, 2018. 